\title{
POTENSI DAN MASALAH DESA WISATA BATIK: STUDI KASUS DESA GIRILAYU, KABUPATEN KARANGANYAR
}

\author{
Nyta Rosidha Sari1, Paramita Rahayu', Erma Fitria Rini1 \\ 1Program Studi Perencanaan Wilayah dan Kota, Fakultas Teknik, Universitas Sebelas Maret
}

\begin{abstract}
Abstrak
Saat ini pengembangan desa wisata tengah gencar dilakukan di Indonesia. Salah satu desa di Kabupaten Karanganyar yang dicanangkan sebagai desa wisata yaitu Desa Girilayu. Desa Girilayu berada di Kecamatan Matesih, Kabupaten Karanganyar. Pencanangan Desa Girilayu sebagai desa wisata dilakukan setelah penetapan desa tersebut sebagai Desa Vokasi pada tahun 2013 oleh Pemerintah Kabupaten Karanganyar. Penetapan sebagai desa wisata dilakukan karena mayoritas masyarakat Desa Girilayu memiliki keahlian membatik dan Desa Girilayu merupakan sentra batik tulis di Kabupaten Karanganyar. Meskipun Desa Girilayu telah memiliki beberapa potensi wisata, untuk menjadi sebuah desa wisata harus memenuhi beberapa komponen spesifik pengembangan desa wisata. Berdasarkan hal tersebut, penelitian ini bertujuan untuk menilai potensi dan masalah yang ada pada Desa Wisata Batik Girilayu berdasarkan komponen desa wisata. Pendekatan yang digunakan dalam penelitian ini adalah metode deskriptif kuantitatif dengan menggunakan analisis SWOT EFAS-IFAS. Hasil penelitian menunjukkan bahwa Desa Wisata Batik Girilayu berada pada kuadran I diagram Kartesius, yang berarti secara keseluruhan memiliki potensi kekuatan dari dalam kawasan dan potensi peluang pengembangan dari luar kawasan. Komponen atraksi, fasilitas penunjang, akomodasi, transportasi dan aksesibilitas serta hospitality dinilai sebagai potensi kekuatan dari dalam kawasan dan memilki potensi peluang pengembangan. Untuk kesadaran masyarakat hasil studi ini menunjukkan bahwa komponen tersebut masih cenderunng lemah, tetapi tetap dapat dikatakan sudah berpotensi dalam hal pengembangan dari luar kawasan. Komponen ini cenderung lemah karena pengelola Desa Wisata Batik Girilayu belum terbentuk sehingga program pengembangan desa wisata belum terlaksana dan belum memiliki arah yang jelas.
\end{abstract}

Kata kunci: Desa Girilayu; desa wisata; desa wisata batik; komponen desa wisata

\begin{abstract}
The development of tourism village is currently being intensively carried out in Indonesia. One of the villages in Karanganyar Regency which is declared as a tourism village is Girilayu Village. $f$ Girilayu Village is located in Matesih District, Karanganyar Regency. The declaration of Girilayu Village as a tourism village is conducted after its designation as a Vocational Village in 2013 by the Karanganyar District Government. The status as Batik Tourism Village is chosen as the majority of Girilayu Villagers have skill to batik craft . More particulalry, Girilayu Village is known as a center of hand-drawn batik in Karanganyar Regency. Even though Girilayu Village has already developed several local tourism potential, to develop as an establihed tourism village, a village must meet several particular components of a tourismvillage. Therefore, this study aims toat assessing the potential and problems that exist in Batik Girilayu Tourism Village based on the particular components of tourism village. The approach applied in this research is a quantitative method using the EFAS-IFAS SWOT analysis. The results show that the Girilayu Batik Tourism Village is in quadrant I of the Cartesian diagram thatmeans, overall, the village has the potential of internal strengthfrom within-factorsand the development opportunities from external or outside region-factors. Factors of attractions, supporting facilities, accommodation, transportation and accessibility as well as hospitality are considered as having the potential of internal strengthfrom within the region and the potential of development from external or outside the region. The community awareness factor is considered as weaknesses aspect from within the region, but it has the potential of development from external or outside the region. This is because the manager of the Girilayu Batik Tourism Village has not yet been established, so the tourism village development program has not been implemented and the direction is remain unclear.
\end{abstract}

Keywords: batik tourism village; Girilayu Village; tourism village; tourism village component

\section{PENDAHULUAN}

Saat ini Kementerian Pariwisata Indonesia tengah gencar melakukan pengembangan wisata pedesaan. Pemerintah Kota/Kabupaten berlomba-lomba untuk mengembangkan kawasan pedesaannya dengan cara memberikan ciri khas pada kawasan desanya masing-masing. Nantinya desa ini diharapkan mampu meningkatkan nilai jual desa untuk 
dikembangkan menjadi desa wisata. Akan tetapi, ada desa wisata yang terbentuk karena 'program latahan', yaitu desa wisata yang berdiri karena desa tersebut memiliki objek wisata.

Adapun pengertian desa wisata yaitu suatu bentuk integrasi antara atraksi, akomodasi dan fasilitas pendukung yang disajikan dalam suatu struktur kehidupan masyarakat yang menyatu dengan tata cara dan tradisi yang berlaku (Nuryanti, 1993). Berdasarkan pengertian tersebut dapat diketahui bahwa tidak semua desa dapat dikatakan sebagai desa wisata. Tentunya hanya desa-desa yang memenuhi syarat memiliki komponen desa wisata yang dapat ditetapkan sebagai desa wisata karena dari komponen desa wisata dapat diketahui potensi maupun masalah dari desa yang akan dikembangkan sebagai desa wisata. Menurut Priasukmana dan Mulyadin (2001), desa wisata harus memenuhi syarat, yaitu: (1) aksesibilitas yang baik, mudah dijangkau dengan berbagai jenis transportasi, (2) memiliki objek menarik, berupa alam, seni budaya, legenda, makanan lokal dan sebagainya untuk dikembangkan sebagai daya tarik wisata, (3) adanya dukungan dari masyarakat dan aparat desa, (4) terjaminnya keamanan pada desa tersebut, (5) tersedianya akomodasi, telekomunikasi dan tenaga kerja yang memadai, (6) beriklim sejuk dan dingin, (7) berhubungan dengan objek wisata lain yang sudah dikenal oleh masyarakat luas.

Kabupaten yang mulai melakukan pengembangan desa wisata yaitu Kabupaten Karanganyar. Kabupaten Karanganyar merupakan salah satu kabupaten di Provinsi Jawa Tengah yang berbatasan langsung dengan bagian timur Kota Surakarta. Kabupaten Karanganyar memiliki 17 kecamatan dan 177 kelurahan/desa dengan luas wilayah mencapai $772,20 \mathrm{~km}$. Kabupaten Karanganyar memiliki ketinggian kisaran 80-2000 meter di atas permukaan laut dan terletak di kaki Gunung Lawu, yang menjadikan wilayah ini berudara sejuk dengan pemandangan alam yang indah. Dalam kebijakan penataan ruang Rencana Tata Ruang Wilayah Kabupaten Karanganyar tahun 2013-2032, Kabupaten Karanganyar akan melakukan pengembangan wilayah dengan tiga pilar, yaitu Industri, Pertanian dan Pariwisata (INTANPARI). Kemudian dalam strategi penataan ruang juga dijelaskan Kabupaten Karanganyar akan mengembangkan kegiatan pariwisata alam dan budaya pada bagian timur wilayah Karanganyar sebagai penggerak utama dan potensi pariwisata lainnya sebagai pendukung. Hal ini didukung dengan adanya strategi pembangunan sarana dan prasarana penunjang pariwisata seperti transportasi guna meningkatkan aksesibilitas pendukung pariwisata. Kemudian dalam strategi pengembangan kawasan pariwisata juga disebutkan bahwa Kabupaten Karanganyar akan mengembangkan potensi desa sebagai daya tarik desa wisata. Adapun lokasi pengembangan berada di Kecamatan Tawangmangu, Kecamatan Ngargoyoso, Kecamatan Jenawi, Kecamatan Kerjo, Kecamatan Karangpandan, Kecamatan Karanganyar, Kecamatan Tasikmadu, Kecamatan Gondangrejo dan Kecamatan Matesih. Pengembangan desa ini didukung dengan Misi Kabupaten Karanganyar point 4, yakni pembangunan desa sebagai pusat pertumbuhan. Pada Perda No 6 Tahun 2016 tentang Rencana Induk Pembangunan Kepariwisataan (Riparda) Kabupaten Karanganyar tahun 2016-2026, Kecamatan Matesih masuk ke dalam Wilayah Pengembangan Pariwisata (WPP Selatan) Kabupaten Karanganyar dan merupakan Kawasan Pengembangan Pariwisata Kabupaten (KPPK), yaitu area atau kawasan tertentu dengan komponen kepariwisataan, serta memiliki karakter atau tema produk wisata tertentu yang dominan dan melekat kuat sebagai komponen pencitraan kawasan.

Kecamatan Matesih terbagi menjadi 9 wilayah desa, salah satu desa yang sudah dicanangkan sebagai desa wisata yaitu Desa Girilayu. Desa Girilayu merupakan sentra batik tulis (desa pembatik Mangkunegaran) di Kabupaten Karanganyar. Pengembangan pariwisata Desa Wisata Batik Girilayu ini menyajikan desa wisata berbasis kearifan lokal masyarakat desa. Selain sebagai sentra batik tulis Kabupaten Karanganyar, pada Desa Wisata Batik Girilayu juga terdapat makam keluarga Raja-raja Mangkunegaran (Astana Mangadeg dan Astana Girilayu) serta berdekatan dengan Astana Giribangun (makam keluarga Soeharto) yang merupakan salah satu wisata ziarah di Kabupaten Karanganyar. Walaupun sudah memiliki potensi daya tarik wisata, akan tetapi perkembangan Desa Wisata Batik Girilayu masih jalan ditempat. Oleh karena itu, akan dilakukan penelitian tentang penilaian potensi dan masalah Desa Wisata Batik Girilayu berdasarkan komponen desa wisata untuk mengetahui komponen desa wisata yang potensial maupun kurang potensial.

\section{KAJIAN PUSTAKA}

Penelitian ini merupakan penelitian kuantitatif menggunakan teori yang terkait dengan penelitian sebagai landasan dalam melaksanakan penelitian. Kajian teori yang digunakan dalam penentuan variabel dan sub variabel dijabarkan sebagai berikut:

\subsection{PENGERTIAN PARIWISATA}

Pariwisata merupakan suatu bentuk perpindahan tempat sementara seseorang di luar tempat tinggalnya karena suatu alasan tertentu dan bukan untuk melakukan kegiatan yang menghasilkan uang (Suwantoro, 2004). Dengan demikian 
dapat dikatakan pariwisata merupakan kegiatan pindahan tempat seseorang karena tujuan tertentu untuk mendapatkan suatu kepuasan. Kepuasan ini dapat berupa hiburan, olahraga, maupun kesenangan tersendiri. Sedangkan pada UU No. 10 Tahun 2009 Tentang Kepariwisataan dijelaskan, pariwisata adalah berbagai macam kegiatan wisata didukung berbagai fasilitas dan layanan yang disediakan oleh masyarakat, pengusaha, Pemerintah, dan Pemerintah Daerah. Maka dapat dikatakan bahwa pariwisata bergantung pada partisipasi dari masyarakat maupun pemerintah karena pariwisata merupakan salah satu jenis industri baru yang mampu mempercepat pertumbuhan ekonomi dalam penyediaan lapangan pekerjaan, peningkatan penghasilan, standar hidup serta menstimulan produktivitas sektor-sektor lain (Wahab, 1975).

Dari penjelasan para ahli di atas dapat disimpulkan bahwa pariwisata merupakan kegiatan wisata yang dilakukan masyarakat dengan tujuan tertentu untuk mendapatkan kepuasan tersendiri serta kegiatan pariwisata ini tidak bertujuan untuk mendapatkan upah. Selain itu, pariwisata dapat berjalan dengan adanya dukungan dari masyarakat, pengusaha dan pemerintah dalam penyediaan fasilitas pariwisata maupun usaha-usaha yang berhubungan dengan penyelenggaraan pariwisata. Tujuan dari kegiatan pariwisata ini untuk mempercepat pertumbuhan ekonomi dalam penyediaan lapangan pekerjaan, peningkatan penghasilan, standar hidup serta sebagai stimulan produktivitas sektor-sektor lain yang berhubungan dengan pariwisata.

\subsection{KOMPONEN PARIWISATA}

Komponen pariwisata merupakan segala sesuatu yang harus ada pada suatu tempat wisata sebagai penunjang kegiatan pariwisata. Inskeep (1991) menjelaskan bahwa komponen wisata merupakan dasar dari kawasan wisata yang saling terintegrasi satu sama lain dalam mewujudkan kegiatan kawasan wisata. Komponen tersebut, yaitu atraksi wisata dan kegiatan wisata, fasilitas dan pelayanan akomodasi, fasilitas dan pelayanan wisata lain, fasilitas dan pelayanan trasportasi, infrastruktur dan aspek kelembagaan. Menurut Yoeti (2002), produk wisata sebagai salah satu objek penawaran dalam pemasaran pariwisata memiliki unsur-unsur utama yang terdiri dari: (1) daya tarik daerah tujuan wisata, termasuk di dalamnya citra yang dibayangkan oleh wisatawan, (2) fasilitas yang dimiliki daerah tujuan wisata, meliputi akomodasi, usaha pengolahan makanan, parkir, trasportasi, rekreasi dan lain-lain, (3) kemudahan untuk mencapai daerah tujuan wisata tersebut. Selain itu Pendit (1994) berpendapat, unsur-unsur yang terlibat dalam industri pariwisata, meliputi (1) akomodasi, tempat seseorang untuk tinggal sementara, (2) jasa boga dan restoran yang merupakan industri jasa di bidang penyelenggaraan makanan dan minuman yang dikelola secara komersial, (3) transportasi dan jasa angkutan, baik itu industri usaha jasa yang bergerak di bidang angkutan darat, laut dan udara, (4) atraksi wisata yang dapat menarik perhatian wisatawan atau pengunjung, (5) cendera mata (suvenir) yang dijadikan kenang-kenangan untuk dibawa oleh wisatawan pada saat kembali ke tempat asal, serta (6) biro perjalanan atau badan usaha pelayanan semua proses perjalanan dari berangkat hingga kembali.

Kemudian Spillane (1994) menjelaskan jika suatu objek wisata atau destination harus meliputi lima unsur penting agar wisatawan dapat merasa puas dalam menikmati perjalanannya, maka objek wisata harus, meliputi (1) attractions yang merupakan pusat dari industri pariwisata digunakan untuk menarik minat wisatawan untuk mengunjungi suatu lokasi karena ciri-ciri khas tertentu, seperti keindahan alam, iklim dan cuaca, kebudayaan maupun sejarah, (2) facility yang cenderung berorientasi pada attractions di suatu lokasi karena fasilitas cenderung mendukung bukan mendorong pertumbuhan dan cenderung berkembang pada saat yang sama atau sesudah attractions berkembang, (3) infrastructure merupakan semua konstruksi di bawah dan di atas tanah suatu wilayah atau daerah, meliputi ketersediaan air bersih, sumber listrik dan energi, jaringan komunikasi, sistem persampahan, jasa kesehatan maupun jalan, (4) transportation yang merupakan fasilitas untuk mempermudah masyarakat mengakses tempat wisata, seperti angkutan wisata, terminal dan jadwal keberangkatan, (5) hospitality (keramah-tamahan) merupakan kepastian akan jaminan keamanan wisatawan yang sedang berada dalam lingkungan yang belum mereka kenal, khususnya wisatawan asing.

\subsection{PENGERTIAN DESA WISATA}

Desa wisata adalah suatu bentuk integrasi antara atraksi, akomodasi dan fasilitas pendukung yang disajikan dalam suatu struktur kehidupan masyarakat yang menyatu dengan tata cara dan tradisi yang berlaku (Nuryanti, 1993). Menurut Priasukmana \& Mulyadin (2001), desa wisata merupakan suatu kawasan pedesaan yang menawarkan suasana yang mencerminkan keaslian pedesaan baik dari kehidupan sosial ekonomi, sosial budaya, adat istiadat, dan keseharian memiliki arsitektur bangunan dan struktur tata ruang desa yang khas, atau kegiatan perekonomian yang unik dan menarik serta mempunyai potensi untuk dikembangkan berbagai komponen kepariwisataan, misalnya atraksi, akomodasi, makanan-minuman, cendera mata, dan kebutuhan wisata lainnya. Desa wisata dilihat sebagai bentuk industri pariwisata berupa kegiatan mengaktualisasikan perjalanan wisata, meliputi sejumlah kegiatan yang bersifat menghimbau, merayu, 
mendorong wisatawan sebagai konsumen agar menggunakan produk dari desa wisata tersebut atau mengadakan perjalanan wisata ke desa wisata tersebut atau disebut pemasaran desa wisata (Soekadijo, 2000).

Dari penjelasan para ahli dapat ditarik kesimpulan bahwa desa wisata merupakan bentuk integrasi antara potensi dan fasilitas pendukung pariwisata baik berupa sosial budaya masyarakat, sosial ekonomi, kesenian, adat istiadat maupun tata ruang desa yang khas sehingga dapat dilihat sebagai bentuk daya tarik maupun industri pariwisata pedesaan, sehingga para wisatawan dapat membaur dengan masyarakat desa dan menikmati suasana pedesaan.

\subsection{KOMPONEN DESA WISATA}

Tidak semua desa bisa disebut sebagai desa wisata, adapun desa yang dapat dijadikan sebagai desa wisata, yaitu desa-desa yang sudah memenuhi komponen desa wisata yang telah ditentukan. Menurut Nuryanti (1993), terdapat tiga konsep utama dalam komponen desa wisata, yaitu (1) akomodasi sebagian dari tempat tinggal para penduduk setempat dan unit-unit berkembang atas konsep tempat tinggal penduduk, (2) atraksi berupa seluruh kehidupan keseharian penduduk setempat beserta setting fisik lokasi desa yang memungkinkan terintegrasinya wisatawan sebagai partisipan aktif, seperti kursus tari, bahasa dan lain-lain yang spesifik, (3) keindahan alam, keunikan dan kelangkaan desa wisata itu sendiri. Kemudian Priasukmana dan Mulyadin (2001) berpendapat bahwa penetapan suatu desa sebagai desa wisata harus memenuhi persyaratan, di antaranya: (1) aksesibilitasnya yang baik sehingga mudah dikunjungi wisatawan dengan menggunakan berbagai jenis alat transportasi, (2) memiliki objek-objek menarik berupa alam, seni budaya, legenda, makanan lokal, dan sebagainya untuk dikembangkan sebagai objek wisata, (3) masyarakat dan aparat desanya menerima dan memberikan dukungan yang tinggi terhadap desa wisata serta para wisatawan yang datang ke desanya, (4) keamanan di desa tersebut terjamin, (5) tersedia akomodasi, telekomunikasi, dan tenaga kerja yang memadai, (6) beriklim sejuk atau dingin, (7) berhubungan dengan objek wisata lain yang sudah dikenal oleh masyarakat luas.

Adapun menurut Fandeli (2002), desa wisata sebagai suatu wilayah pedesaan yang menawarkan keseluruhan suasana yang mencerminkan keaslian desa, baik dari segi kehidupan sosial budaya, adat istiadat, aktifitas keseharian, arsitektur bangunan, dan struktur tata ruang desa, serta potensi yang mampu dikembangkan sebagai daya tarik wisata, misalnya atraksi, makanan dan minuman, cindera mata, penginapan, dan kebutuhan wisata lainnya.

\section{METODE PENELITIAN}

Penelitian ini menggunakan pendekatan deskriptif kuantitatif. Adapun penelitian deskriptif biasanya terpusat pada aspek-aspek tertentu dan sering kali menunjukkan hubungan antar variabel yang ada (Nasution, 2003). Penggunaan jenis kuantitatif dalam penelitian ini karena penelitian ini memiliki dasar yang jelas, seperti tujuan, subjek, sumber data, sampel, desain penelitian, analisis data, jadwal, dan alokasi dana (Arikunto, 2006). Sesuai hasil sintesis teori komponen wisata dan komponen desa wisata diperoleh variabel penelitian seperti pada Tabel 1.

Tabel 1. Variabel Penelitian

\begin{tabular}{|c|c|c|c|}
\hline $\begin{array}{l}\text { Komponen } \\
\text { Wisata } \\
\text { (Variabel) }\end{array}$ & $\begin{array}{c}\text { Komponen Desa Wisata } \\
\text { (Sub Variabel) }\end{array}$ & Definisi Operasional & Sumber \\
\hline Atraksi & $\begin{array}{l}\text { - Adanya atraksi pada desa wisata } \\
\text { - } \quad \text { Adanya keunikan desa } \\
\text { - } \quad \text { Adat istiadat dan budaya yang ada } \\
\text { di desa wisata } \\
\text { - Kehidupan sosial masyarakat desa } \\
\text { - Wilayah pedesaan berudara sejuk }\end{array}$ & $\begin{array}{l}\text { Kegiatan pariwisata yang digunakan untuk menarik minat } \\
\text { wisatawan agar berkunjung. Atraksi ini bisa berupa } \\
\text { keindahan alam, iklim dan cuaca, kebudayaan dan adat } \\
\text { istiadat, kehidupan keseharian penduduk maupun } \\
\text { keunikan dan kelangkaan dari desa wisata. }\end{array}$ & $\begin{array}{l}\text { Spillane } \\
\text { (1994), } \\
\text { Nuryanti } \\
\text { (1993) }\end{array}$ \\
\hline $\begin{array}{l}\text { Fasilitas } \\
\text { penunjang }\end{array}$ & $\begin{array}{l}\text { - Ketersediaan tempat parkir } \\
\text { - } \quad \text { Ketersediaan tempat makan } \\
\text { - } \text { Ketersediaan fasilitas umum } \\
\text { pemukiman di desa wisata (listrik, } \\
\text { air bersih, telekomunikasi, } \\
\text { kesehatan, pendidikan, } \\
\text { perdagangan jasa, sanitasi, } \\
\text { drainase, persampahan) } \\
\text { - } \quad \text { Ketersediaan toko oleh-oleh }\end{array}$ & $\begin{array}{l}\text { Sarana prasarana yang digunakan sebagai penunjang } \\
\text { kegiatan pariwisata di desa wisata. Adapun fasilitas ini } \\
\text { dapat berupa usaha pengolahan makanan (tempat } \\
\text { makan), tempat parkir, kedekatan dengan tempat wisata } \\
\text { lain, infrastruktur penunjang permukiman (ketersediaan } \\
\text { air bersih, sumber listrik dan energi, jaringan komunikasi, } \\
\text { sistem persampahan, jasa kesehatan, jalan dan lain } \\
\text { sebagainya), toko oleh-oleh dan biro perjalanan. }\end{array}$ & $\begin{array}{l}\text { Yoeti (2002), } \\
\text { Spillane } \\
\text { (1994), } \\
\text { Pendit } \\
\text { (1994) }\end{array}$ \\
\hline
\end{tabular}




\begin{tabular}{|c|c|c|c|}
\hline $\begin{array}{l}\text { Komponen } \\
\text { Wisata } \\
\text { (Variabel) }\end{array}$ & $\begin{array}{l}\text { Komponen Desa Wisata } \\
\text { (Sub Variabel) }\end{array}$ & Definisi Operasional & Sumber \\
\hline & $\begin{array}{l}\text { - Ketersediaan biro perjalanan/ } \\
\text { paket wisata } \\
\text { - Kedekatan dengan objek wisata } \\
\text { lain }\end{array}$ & & \\
\hline Akomodasi & Ketersediaan penginapan (homestay) & $\begin{array}{l}\text { Merupakan suatu tempat menginap yang dapat berupa } \\
\text { penginapan atau rumah warga (homestay) yang } \\
\text { disewakan untuk wisatawan yang berkunjung ke desa } \\
\text { wisata. }\end{array}$ & $\begin{array}{l}\text { Pendit } \\
\text { (1994) } \\
\text { Nuryanti } \\
\text { (1993). }\end{array}$ \\
\hline $\begin{array}{l}\text { Transportasi } \\
\text { dan } \\
\text { Aksesibilitas }\end{array}$ & $\begin{array}{l}\text { - } \text { Ketersediaan angkutan umum } \\
\text { - } \text { Ketersediaan terminal } \\
\text { - } \text { Kemudahan menuju tempat wisata } \\
\text { (akses jalan) }\end{array}$ & $\begin{array}{l}\text { Transportasi merupakan usaha penyedia angkutan yang } \\
\text { dapat digunakan untuk mempermudah masyarakat } \\
\text { mengakses desa wisata. Transportasi ini bisa berupa } \\
\text { angkutan umum, terminal maupun jadwal } \\
\text { keberangkatan. Kemudian untuk aksesibilitas sendiri } \\
\text { yaitu kemudahan wisatawan untuk mengunjungi desa } \\
\text { wisata dengan menggunakan berbagai jenis alat } \\
\text { transportasi yang ada. }\end{array}$ & $\begin{array}{l}\text { Pendit } \\
\text { (1994), } \\
\text { Spillane } \\
\text { (1994), } \\
\text { Priasukmana } \\
\text { dan } \\
\text { Mulyadin } \\
\text { (2001). } \\
\end{array}$ \\
\hline $\begin{array}{l}\text { Kesadaran } \\
\text { Masyarakat }\end{array}$ & $\begin{array}{l}\text { - Adanya kelembagaan yang } \\
\text { berperan dalam pengembangan } \\
\text { ataupun pengelolaan desa wisata } \\
\text { - Adanya partisipasi masyarakat } \\
\text { dalam pengembangan desa wisata }\end{array}$ & $\begin{array}{l}\text { Dukungan dari masyarakat dan aparat desa maupun } \\
\text { kabupaten/kota dalam menerima wisatawan yang } \\
\text { berkunjung ke desanya. Kesadaran dan dukungan } \\
\text { masyarakat serta aparat merupakan partisipasi } \\
\text { masyarakat dalam membentuk kelembagaan yang } \\
\text { bertugas mengelola desa wisata yang ada. }\end{array}$ & $\begin{array}{l}\text { Priasukmana } \\
\text { dan } \\
\text { Mulyadin } \\
\text { (2001). }\end{array}$ \\
\hline Hospitality & $\begin{array}{l}\text { - Keramah-tamahan masyarakat } \\
\text { - Ketersediaan petugas keamanan }\end{array}$ & $\begin{array}{l}\text { Merupakan keramah-tamahan masyarakat serta jaminan } \\
\text { keamanan untuk wisatawan yang berkunjung ke desa } \\
\text { wisata. }\end{array}$ & $\begin{array}{l}\text { Spillane } \\
\text { (1994) }\end{array}$ \\
\hline
\end{tabular}

Pada penelitian ini menggunakan teknik pengumpulan data observasi, wawancara dan kuesioner. Adapun teknik wawancara dan observasi digunakan untuk menggali dan mengidentifikasi potensi dan masalah yang ada pada Desa Wisata Batik Girilayu. Untuk kuesioner digunakan dalam pemberian bobot variabel dan penilaian potensi masalah yang dilakukan oleh responden. Teknik sampling yang digunakan dalam penelitian adalah teknik non random sampling stakeholder mapping dengan didapat responden seperti pada Tabel 2.

Tabel 2. Responden dan Jumlah Sampel

\begin{tabular}{lc}
\multicolumn{1}{c}{ Stakeholder } & Jumlah \\
\hline Dinas Perdagangan, Tenaga Kerja, Koperasi, Usaha Kecil dan Menengah & 1 \\
Dinas Pemberdayaan Masyarakat dan Desa & 1 \\
Dinas Pariwisata Pemuda dan Olahraga & 1 \\
Pemerintah Desa Girilayu & 1 \\
Pengrajin/Pengusaha Batik & 3 \\
KUB/Kelompok Pembatik & 4 \\
Akademisi Bidang Pariwisata & 1 \\
Pemuda Desa & 1 \\
Total & 13 \\
\hline
\end{tabular}

Dalam penelitian ini menggunakan teknik analisis SWOT EFAS-IFAS. Adapun pengertian dari analisi SWOT EFASIFAS adalah pengolahan faktor-faktor strategis pada lingkungan internal dan eksternal dengan memberikan pembobotan dan rating pada setiap faktor strategis (Rangkuti, 2001). Dalam hal ini dilakukan identifikasi potensi dan masalah yang ada pada Desa Wisata Batik Girilayu. Setelah itu dilakukan pengelompokkan potensi dan masalah sesuai konsep SWOT kemudian responden diminta untuk memberikan bobot pada komponen wisata dan memberikan penilaian pada potensi dan masalah yang telah dikelompokkan. Setelah responden memberikan penilaian, kemudian dilakukan penghitungan skor dengan cara mengalikan bobot dengan nilai dari potensi dan masalah. Setelah skor diperoleh, kemudian dilakukan penghitungan selisih nilai tertimbang dengan cara mengurangkan nilai kekuatan (S) dengan nilai kelemahan (W) dan mengurangkan nilai peluang $(\mathrm{O})$ dengan nilai ancaman $(\mathrm{T})$. Hasil penghitungan nilai tertimbang diaplikasikan dalam diagram Kartesius (lihat Gambar 1) untuk mengetahui kedudukan dari Desa Wisata Batik Girilayu. 


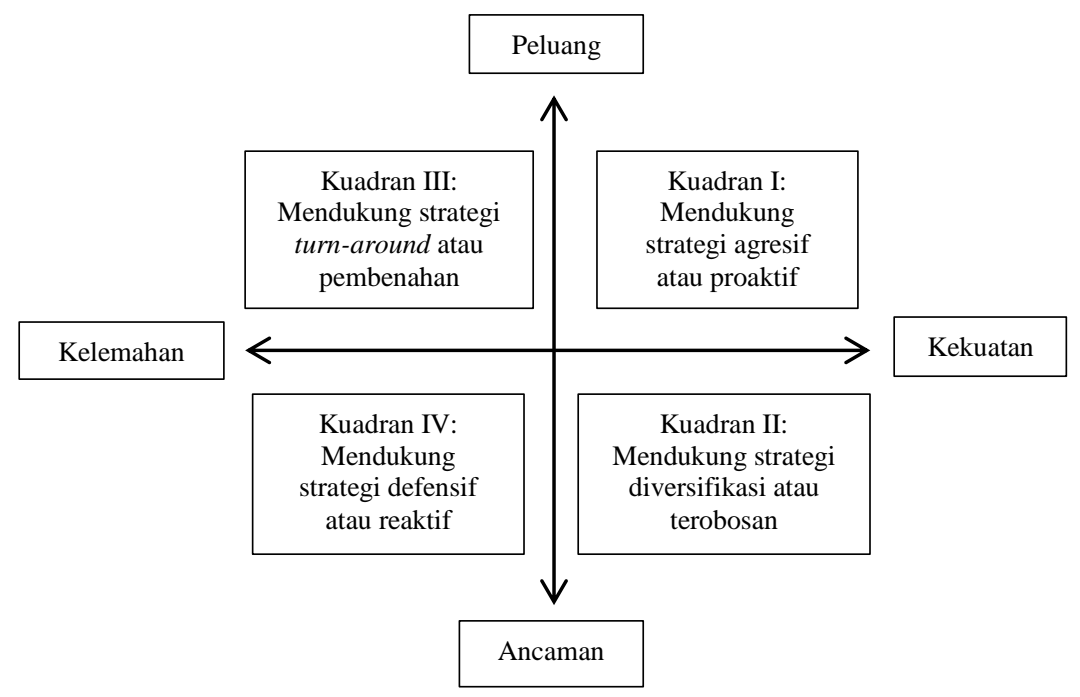

Sumber: Rangkuti, 2001

\section{Gambar 1. Diagram Kartesius}

Menurut Rangkuti (2001), maksud dari masing-masing kuadran dalam diagram , yaitu: (1) kuadran I, merupakan situasi yang sangat menguntungkan dimana memiliki peluang dan kekuatan sehingga dapat memanfaatkan peluang yang ada, strategi yang dapat diterapkan dalam kondisi seperti ini, yaitu mendukung kebijakan pertumbuhan yang agresif, (2) kuadran II, menghadapi berbagai ancaman namun masih memiliki kekuatan dari segi internal, strategi yang dapat diterapkan dalam kondisi seperti ini, yaitu menggunakan kekuatan untuk memanfaatkan peluang jangka panjang dengan cara diversifikasi, (3) kuadran III, menghadapi peluang yang sangat besar akan tetapi di lain pihak menghadapi kendala atau kelemahan internal sehingga strategi yang dapat diterapkan adalah meminimalisir masalah internal sehingga dapat memanfaatkan peluang pasar yang lebih baik, (4) kuadran IV, merupakan situasi yang sangat tidak menguntungkan, dalam hal ini menghadapi berbagai ancaman dan kelemahan internal.

\section{HASIL DAN PEMBAHASAN}

Dalam hal ini akan dijabarkan mengenai data dan hasil dari analisis SWOT EFAS-IFAS yang digunakan dalam penelitian. Berikut ini merupakan penjabarannya.

\subsection{GAMBARAN UMUM KAWASAN PENELITIAN}

Desa Girilayu terletak di Kecamatan Matesih, Kabupaten Karanganyar dengan luas wilayah sebesar 311.541 Ha dan berada pada daerah perbukitan. Adapun jumlah penduduk di Desa Girilayu sebanyak 3779 jiwa dengan dominasi mata pencaharian penduduk sebagai petani (BPS, 2018). Selain sebagai petani, mayoritas penduduk Desa Girilayu memiliki keahlian membatik dan bekerja sebagai pembatik. Berdasarkan hal tersebut Desa Girilayu pada tahun 2013 ditetapkan sebagai Desa Vokasi sekaligus sebagai sentra batik tulis di Kabupaten Karanganyar. Adapun untuk batas administrasi Desa Girilayu dapat dilihat pada Gambar 2. 


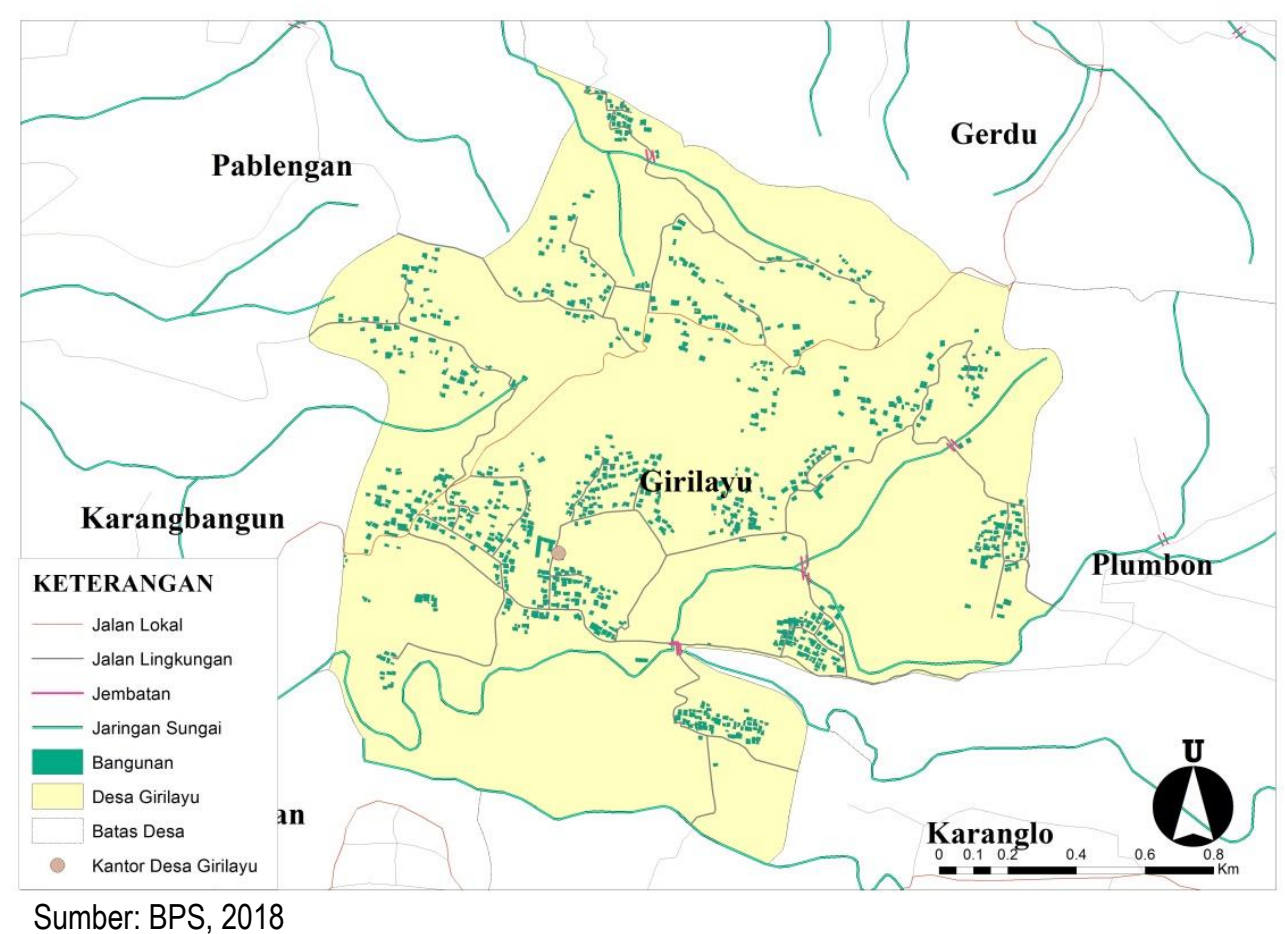

Gambar 2. Administrasi Desa Girilayu

\subsection{DATA}

Adapun data yang diperoleh dari kegiatan observasi lapangan dan wawancara yang nantinya akan digunakan dalam penelitian berupa:

\subsubsection{Atraksi}

Atraksi merupakan komponen penting dalam pariwisata karena atraksi sebagai daya tarik dari objek wisata agar menarik minat wisatawan untuk berkunjung. Adapun atraksi utama yang ada pada Desa Wisata Batik Girilayu berupa pelatihan membatik dari proses mencanting sampai dengan pewarnaan. Untuk alat dan bahan membatik sudah disiapkan oleh kelompok batik maupun pengrajin batik yang menyelenggarakan pelatihan membatik. Selain itu, pada Desa Wisata Batik Girilayu juga terdapat makam keluarga Raja-raja Mangkunegaran yaitu Astana Girilayu (komplek makam keluarga Raja Mangkunegaran IV, Mangkunegaran V, Mangkunegaran VII dan Mangkunegaran VIII) dan Astana Mangadeg (komplek makam keluarga Raja Mangkunegaran I, Mangkunegaran II dan Mangkunegaran III). Selain itu, Desa Girilayu berbatasan langsung dengan Astana Giribangun yang merupakan makam keluarga Soeharto (mantan presiden Republik Indonesia). Oleh karena itu, Desa Girilayu dijadikan salah satu objek wisata ziarah di Kabupaten Karanganyar. Selain itu pada Desa Wisata Batik Girilayu juga terdapat home industry blangkon, grubi dan tikar anyam yang dapat dikunjungi wisatawan untuk mengetahui proses pembuatannya. Kemudian ada wisata tubing pada Desa Wisata Batik Girilayu, namun wisata tubing ini sudah tidak beroperasi. Adapun untuk lokasi atraksi Desa Wisata Batik Girilayu dapat dilihat pada Gambar 3. 


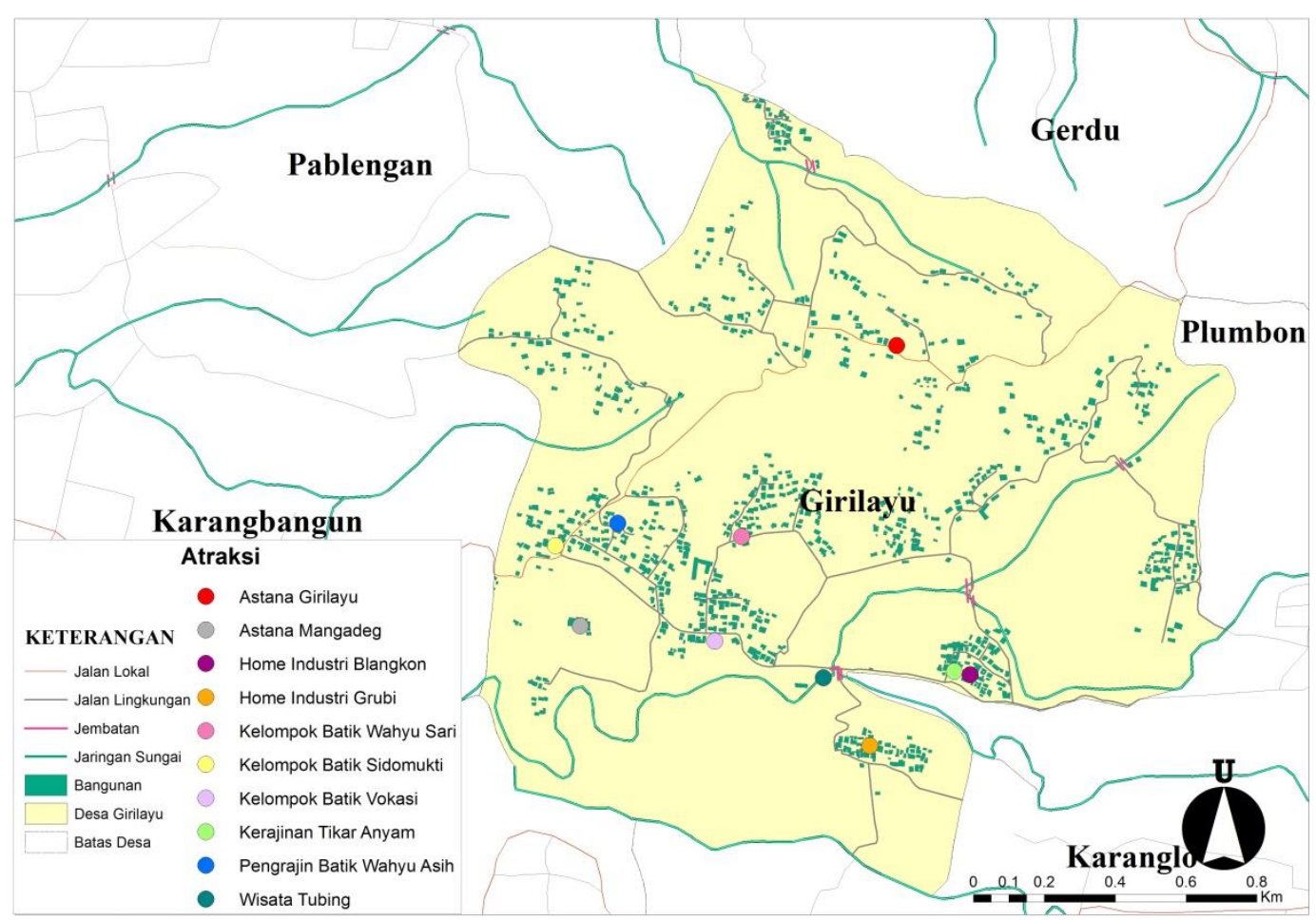

Gambar 3. Peta Atraksi pada Desa Wisata Batik Girilayu

\subsubsection{Fasilitas Penunjang}

Fasilitas penunjang merupakan sarana yang ada pada desa wisata yang dapat dimanfaatkan sebagai sarana penunjang wisata. Identifikasi fasilitas penunjang dilakukan untuk mengetahui potensi dan masalah pada fasilitas penunjang desa wisata agar nantinya dapat dilakukan pengembangan maupun perbaikan.

Pada Desa Wisata Batik Girilayu sudah terdapat fasilitas umum pemukiman, seperti jaringan air bersih (Pamsimas), jaringan listrik (PLN), jaringan telakomunikasi (memanfaatkan jaringan tower BTS yang ada di Kecamatan Matesih dan Kecamatan Tawangmangu), jaringan drainase berupa sungai (drainase primer) dan saluran air hujan (selokan) yang ada pada setiap pekarangan rumah warga dan mengikuti jalan. Untuk sarana kesehatan sudah terdapat Polindes dan Rumah Praktik Bidan yang dimanfaatkan masyarakat untuk berobat. Kemudian untuk sarana pendidikan sudah ada TK dan dua SD, yaitu SD 01 Girilayu dan SD 03 Girilayu. Pada Desa Wisata Batik Girilayu belum terdapat jaringan sanitasi limbah industri (kecuali Kelompok Batik Vokasi yang sudah memiliki penampungan limbah produksi batik). Sehingga limbah pewarnaan batik langsung dibuang di pekarangan rumah warga dan limbah rumah tangga dibuang masyarakat pada septic tank rumah masing-masing. Kemudian tidak terdapat jaringan persampahan pada Desa Girilayu, sehingga masyarakat biasa mengubur dan membakar sampah rumah tangga di pekarangan rumah.

Untuk fasilitas penunjang wisata, pada Desa Wisata Batik Girilayu belum terdapat usaha tempat makan, kantor informasi dan biro perjalanan wisata. Selain itu, juga belum ada tempat parkir khusus wisata untuk pengunjung desa wisata sehingga wisatawan yang berkunjung memarkirkan bus wisata pada bahu jalan desa. Akan tetapi, untuk kendaraan sepeda motor dan mobil dapat memarkirkan kendaraanya pada tempat parkir Astana Mangadeg dan Astana Girilayu. Selain itu, wisatawan juga dapat memanfaatkan parkiran C Giribangun untuk memarkirkan bus wisata dan menyewa mobil wisata yang sudah tersedia di tempat parkir C Giribangun untuk menuju Desa Wisata Batik Girilayu.

Pada Desa Wisata Batik Girilayu belum terdapat showroom dan toko oleh-oleh. Akan tetapi pada setiap kelompok batik maupun pengrajin batik sudah memiliki mini showroom pada tempat tinggal maupun tempat usahanya masingmasing. Kemudian terdapat mini showroom batik Prajnaparamita yang memasarkan produk batik lokal Desa Girilayu melalui media online (website maupun media sosial). Sebenarnya sudah terdapat showroom pada Terminal Wisata Makuthoromo yang dapat dimanfaatkan sebagai sarana pemasaran produk lokal Desa Wisata Batik Girilayu. Akan tetapi showroom ini belum dimanfaatkan secara optimal oleh kelompok batik maupun pengrajin batik. Selain itu saat ini masyarakat juga memasarkan produk lokal desa pada toko oleh-oleh yang ada di Astana Giribangun. 
Kemudian untuk kedekatan dengan objek wisata lain yang dikenal oleh masyarakat luas, Desa Wisata Batik Girilayu berbatasan langsung dengan Astana Giribangun yang merupakan komplek pemakaman keluarga Soeharto (mantan Presiden Republik Indonesia) yang sering dikunjungi wisatawan untuk berziarah. Selain itu, Desa Wisata Batik Girilayu juga dekat dengan objek wisata Sapta Tirta (berjarak $\pm 5 \mathrm{~km}$ dari Desa Wisata Batik Girilayu), Agrowisata Amanah (berjarak $\pm 6,7 \mathrm{~km}$ dari Desa Wisata Batik Girilayu), dan wisata Kebun Teh Kemuning (berjarak $\pm 12 \mathrm{~km}$ ). Untuk lokasi fasilitas penunjang yang ada pada Desa Wisata Batik Girilayu dapat dilihat pada Gambar 4.

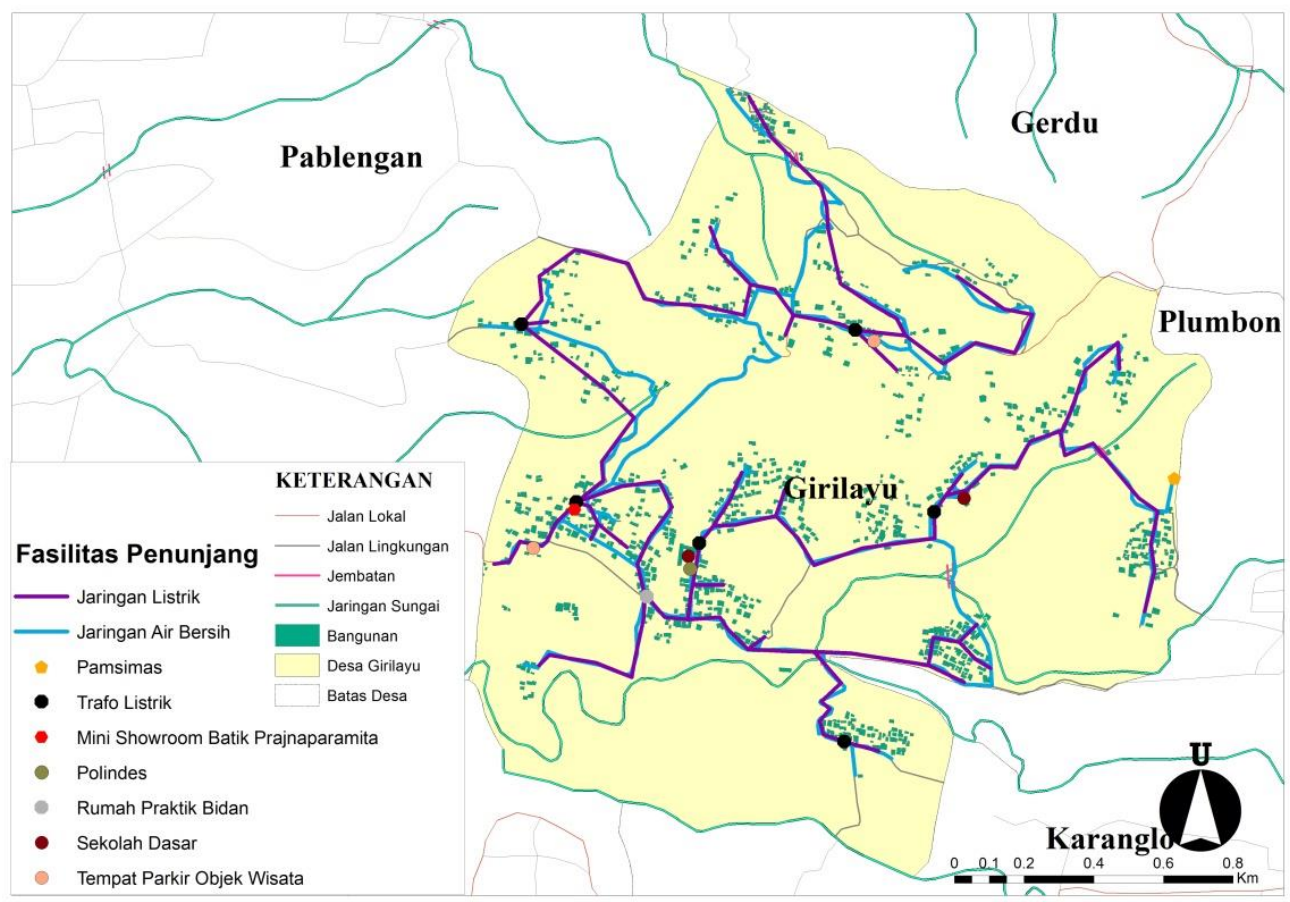

Gambar 4. Fasilitas Penunjang pada Desa Wisata Batik Girilayu

\subsubsection{Akomodasi}

Akomodasi merupakan sarana yang dapat dimanfaatkan wisatawan untuk menginap. Pada Desa Wisata Batik Girilayu sudah mulai muncul homestay dari warga desa. Akan tetapi, homestay ini belum terdata dan terorganisasi. Selin itu, juga sudah mulai dilakukan pembangunan penginapan oleh investor di Desa Wisata Batik Girilayu.

\subsubsection{Transportasi dan Aksesibilitas}

Suatu objek wisata harus mudah dijangkau apabila ingin dikunjungi banyak wisatawan. Transportasi dan aksesibilitas merupakan penentu dari kemudahan untuk dijangkaunya suatu objek wisata. Jaringan jalan pada Desa Wisata Batik Girilayu sudah menggunakan perkerasan aspal dan rabat beton. Desa Wisata Batik Girilayu dilalui jaringan jalan lokal sehingga terdapat Angkutan Desa (Angkudes) yang melewati Desa Girilayu (Angkudes $\mathrm{G}$ dengan trayek Terminal Matesih - Terminal Karangpandan dan sebaliknya). Desa Wisata Batik Girilayu juga dekat dengan Terminal Matesih (terminal penumpang tipe $C$ yang berjarak $\pm 5.1 \mathrm{Km}$ ), Terminal Wisata Makuthoromo (berjarak $\pm 9.1 \mathrm{Km}$ ) dan Terminal Karangpandan (berjarak $\pm 9.9 \mathrm{Km}$ ) sehingga lokasinya cukup strategis dikarenakan terminal tersebut dapat digunakan untuk transit wisatawan. Kemudian pada tempat parkir $C$ Astana Giribangun juga terdapat mobil wisata yang dapat disewa oleh wisatawan untuk menuju Desa Wisata Batik Girilayu (karena bus wisata hanya dapat parkir pada terminal C Astana Giribangun).

\subsubsection{Kesadaran Masyarakat}

Kesadaran masyarakat sangat penting dalam pembentukan desa wisata karena masyarakat merupakan kunci dari pengembangan desa wisata. Pada Desa Wisata Batik Girilayu belum dibentuk pengelola desa wisata. Sampai saat ini pengelolaan dilakukan oleh Pemdes Girilayu sehingga potensi desa belum termanfaatkan secara optimal dan program perencanaan pengembangan desa wisata juga belum terealisasi serta tidak jelas arahnya. Selama ini masyarakat sudah berperan aktif dalam kegiatan pelatihan, pemberdayaan masyarakat, pembinaan dan pendampingan yang diadakan oleh 
Pemkab Karanganyar maupun Dinas Provinsi Jawa Tengah. Selain itu, Pemkab Karanganyar juga mengikutsertakan pengrajin maupun kelompok batik Desa Wisata Batik Girilayu dalam event-event daerah maupun nasional.

\subsubsection{Hospitality (Keramah-tamahan)}

Keramah-tamahan dan keamanan menjadi faktor penting untuk menjadikan wisatawan merasa nyaman dan aman ketika mengunjungi suatu objek wisata. Masyarakat Desa Girilayu menyambut baik setiap wisatawan yang berkunjung ke Desa Wisata Batik Girilayu. Hal ini karena keramah-tamahan masyarakat pedesaan masih tertanam pada warga Desa Girilayu. Kemudian pada Desa Wisata Batik Girilayu berlum terdapat petugas keamanan khusus desa wisata. Akan tetapi, sudah terdapat pos kamling dan Linmas atau Hansip pada Desa Girilayu yang bertugas untuk menjaga keamana desa.

Data yang diperoleh kemudian dikelompokkan sesuai potensi dan masalah sehingga diperoleh pengelompokkan potensi dan masalah yang dapat dilihat pada Tabel 3 . 
Tabel 3. Pengelompokan Potensi dan Masalah Desa Wisata Batik Girilayu

\begin{tabular}{|c|c|c|c|c|}
\hline \multirow{2}{*}{$\begin{array}{c}\text { Komponen } \\
\text { Wisata } \\
\text { (Variabel) }\end{array}$} & \multicolumn{2}{|c|}{ Faktor Dari Dalam } & \multicolumn{2}{|c|}{ Faktor Dari Luar } \\
\hline & Kekuatan (Strength) & Kelemahan (Weakness) & Peluang (Opportunity) & Ancaman (Threat) \\
\hline Atraksi & 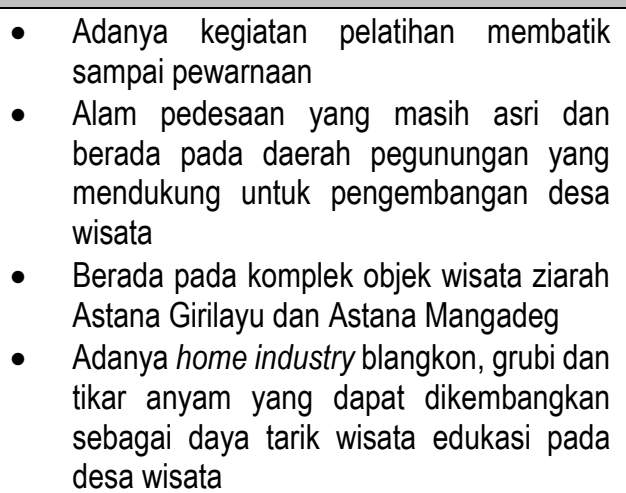 & $\begin{array}{l}\text { - Adanya wisata tubing akan tetapi belum } \\
\text { terkelola dengan baik oleh masyarakat }\end{array}$ & $\begin{array}{l}\text { - Bersebelahan dengan objek wisata } \\
\text { ziarah Astana Giribangun sehingga } \\
\text { dapat menarik minat wisatawan } \\
\text { untuk mendatangi Desa Wisata } \\
\text { Batik Girilayu }\end{array}$ & 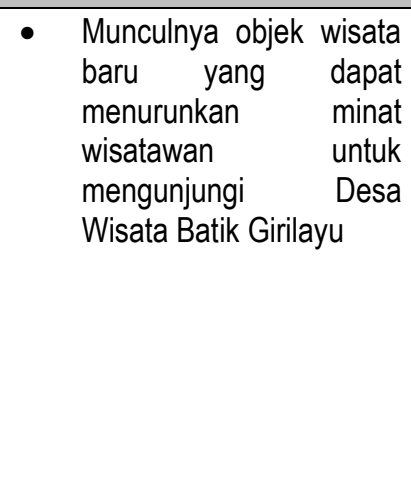 \\
\hline $\begin{array}{l}\text { Fasilitas } \\
\text { penunjang }\end{array}$ & 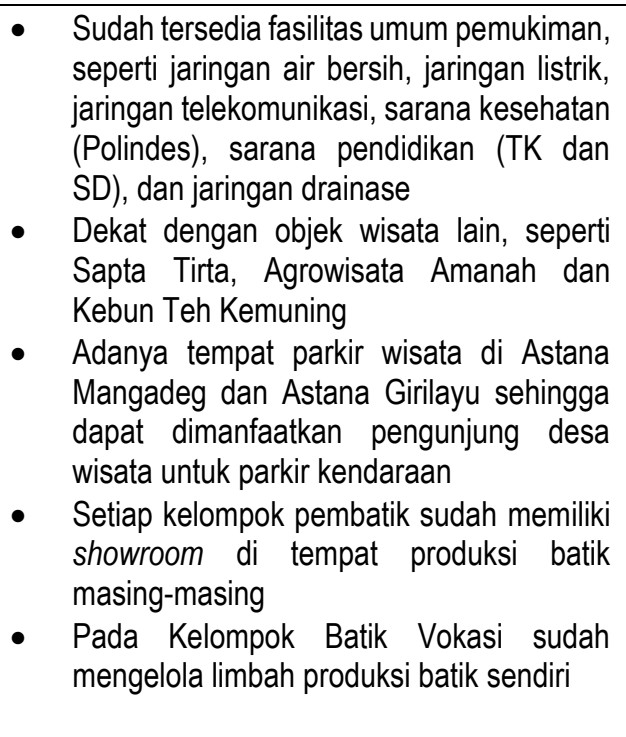 & 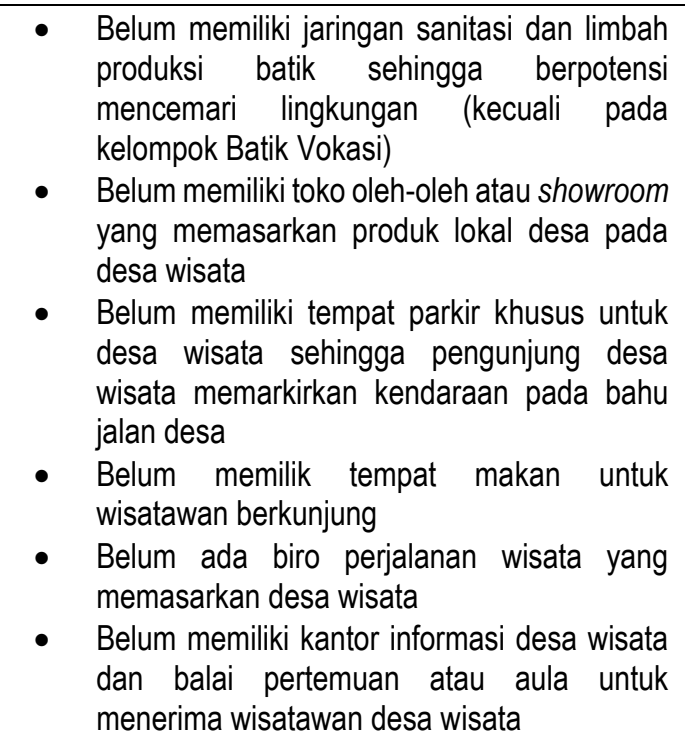 & $\begin{array}{l}\text { - Sudah ada showroom umum pada } \\
\text { Terminal Wisata Makuthoromo } \\
\text { Karangpandan sebagai media } \\
\text { pemasaran produk lokal desa } \\
\text { - Adanya tempat parkir pada objek } \\
\text { wisata Astana Giribangun yang } \\
\text { dapat dimanfaatkan sebagai tempat } \\
\text { parkir pengunjung desa wisata }\end{array}$ & $\begin{array}{l}\text { - Showroom umum pada } \\
\text { Terminal Wisata } \\
\text { Makuthoromo } \\
\text { Karangpandan belum } \\
\text { dioptimalkan } \\
\text { pemanfaatanya karena } \\
\text { belum menampung } \\
\text { produk lokal desa wisata } \\
\text { Untuk bus wisata } \\
\text { biasanya hanya boleh } \\
\text { parkir pada parkiran C } \\
\text { Giribangun sehingga } \\
\text { masyarakat yang } \\
\text { melakukan wisata ziarah } \\
\text { tidak tahu kalau ada desa } \\
\text { wisata yang dapat } \\
\text { dikunjungi }\end{array}$ \\
\hline Akomodasi & $\begin{array}{l}\text { - Masyarakat sudah mulai menjadikan } \\
\text { rumahnya sebagai homestay } \\
\text { - Sudah mulai dibangun penginapan pada } \\
\text { desa wisata oleh investor }\end{array}$ & $\begin{array}{l}\text { - } \text { Karena belum terbentuk pengelola desa wisata } \\
\text { sehingga pendataan dan pengelolaan } \\
\text { homestay belum berjalan } \\
\text { - Pembangunan penginapan yang tengah } \\
\text { dilakukan berpotensi mematikan homestay } \\
\text { warga desa }\end{array}$ & & \\
\hline
\end{tabular}


Desa-Kota, Vol. 3, No. 1, 2021, 77-91

\begin{tabular}{|c|c|c|c|c|}
\hline \multirow{2}{*}{$\begin{array}{l}\text { Komponen } \\
\text { Wisata } \\
\text { (Variabel) }\end{array}$} & \multicolumn{2}{|c|}{ Faktor Dari Dalam } & \multicolumn{2}{|c|}{ Faktor Dari Luar } \\
\hline & Kekuatan (Strength) & Kelemahan (Weakness) & Peluang (Opportunity) & Ancaman (Threat) \\
\hline $\begin{array}{l}\text { Transportasi } \\
\text { dan } \\
\text { Aksesibilitas }\end{array}$ & $\begin{array}{l}\text { - Terdapat jaringan jalan lokal pada desa } \\
\text { wisata sehingga desa wisata dilalui } \\
\text { angkutan desa (angkudes) } \\
\text { - Kualitas jalan sudah baik (perkerasan } \\
\text { aspal) }\end{array}$ & $\begin{array}{l}\text { - Jumlah angkudes berkurang karena minat } \\
\text { masyarakat untuk menggunakan angkudes juga } \\
\text { berkurang }\end{array}$ & $\begin{array}{l}\text { - Desa wisata dekat dengan Terminal } \\
\text { Matesih (terminal tipe C), Terminal } \\
\text { Karangpandan dan Terminal Wisata } \\
\text { Makuthoromo sehingga lokasi cukup } \\
\text { strategis } \\
\text { - Adanya penyewaan mobil wisata } \\
\text { yang dapat digunakan pengunjung } \\
\text { untuk menuju desa wisata dari } \\
\text { parkiran C Giribangun. } \\
\text { Adanya angkudes yang melewati } \\
\text { desa wisata yang dapat digunakan } \\
\text { wisatawan pengguna angkutan } \\
\text { umum untuk menuju desa wisata }\end{array}$ & \\
\hline $\begin{array}{l}\text { Kesadaran } \\
\text { Masyarakat }\end{array}$ & $\begin{array}{l}\text { - Pembatik serta pengrajin batik ikut } \\
\text { berperan serta dalam pemasaran desa } \\
\text { wisata melalui kelompok batik maupun } \\
\text { melalui sosial media masing-masing. }\end{array}$ & $\begin{array}{l}\text { - } \quad \text { Belum adanya pengelola desa wisata sehingga } \\
\text { pengelolaan masih dilakukan pemerintah desa } \\
\text { - Pengelola desa wisata belum terbentuk, } \\
\text { sehingga program desa wisata belum terkelola } \\
\text { dan belum jelas arahnya } \\
\text { - Masih minimnya peran serta masyarakat desa } \\
\text { untuk perkembangan desa wisata (baik berupa } \\
\text { aksi maupun promosi) }\end{array}$ & $\begin{array}{l}\text { - Adanya dukungan dari pemerintah } \\
\text { bagi kelompok maupun pengrajin } \\
\text { batik melalui pelatihan, pembinaan, } \\
\text { pendampingan maupun } \\
\text { mengikutsertakan dalam pameran } \\
\text { nasional dan daerah } \\
\text { - Adanya dukungan dari pemerintah } \\
\text { berupa pemberdayaan masyarakat } \\
\text { desa melalui pelatihan } \\
\text { pengembangan objek wisata desa } \\
\text { wisata } \\
\text { Adanya pelatihan dan sosialisasi } \\
\text { dari Pemkab Karanganyar untuk } \\
\text { pengelolaan dan pengembangan } \\
\text { desa wisata }\end{array}$ & \\
\hline Hospitality & $\begin{array}{l}\text { - Sudah tersedianya petugas keamanan } \\
\text { desa (Linmas atau Hansip) } \\
\text { - } \quad \text { Masyarakat merespon baik dan ramah } \\
\text { setiap adanya kunjungan wisatawan }\end{array}$ & $\begin{array}{l}\text { - Belum adanya petugas keamanan khusus } \\
\text { untuk desa wisata }\end{array}$ & & \\
\hline
\end{tabular}




\subsection{ANALISIS PENILAIAN POTENSI DAN MASALAH}

Analisis yang digunakan dalam penelitian ini adalah teknik analisis SWOT EFAS-IFAS. Analisis SWOT EFAS-IFAS merupakan analisis pengolahan faktor-faktor strategis pada lingkungan internal dan eksternal dengan memberikan pembobotan dan rating pada setiap faktor strategis (Rangkuti, 2001). Adapun tahapan setelah melakukan pengelompokkan potensi dan masalah, yaitu meminta responden untuk memberikan bobot pada masing-masing variabel melalui kuesioner yang telah disusun oleh peneliti. Setelah masing-masing responden memberikan bobot, kemudian bobot tersebut dikompilasi dan dilakukan penghitungan bobot oleh peneliti. Adapun hasil dari perhitungan bobot seperti pada Tabel 4.

Tabel 4. Hasil penghitungan bobot

\begin{tabular}{|c|c|c|c|c|c|c|c|c|c|c|c|c|c|c|c|}
\hline Variabel (Komponen Wisata) & A & $B$ & C & D & $E$ & $\mathbf{F}$ & G & $\mathrm{H}$ & I & $\mathrm{J}$ & $\mathrm{K}$ & $\mathrm{L}$ & M & Total & Bobot \\
\hline Atraksi & 5 & 5 & 5 & 5 & 4 & 5 & 5 & 4 & 5 & 4 & 5 & 5 & 4 & 61 & 0.20 \\
\hline Fasilitas Penunjang & 4 & 4 & 5 & 4 & 5 & 5 & 3 & 5 & 5 & 5 & 5 & 4 & 3 & 57 & 0.18 \\
\hline Akomodasi & 3 & 3 & 4 & 3 & 3 & 3 & 4 & 4 & 4 & 4 & 3 & 3 & 3 & 44 & 0.14 \\
\hline Transportasi dan Aksesibilitas & 4 & 4 & 3 & 4 & 4 & 4 & 4 & 3 & 3 & 3 & 3 & 4 & 3 & 46 & 0.15 \\
\hline Kesadaran Masyarakat & 4 & 5 & 4 & 5 & 5 & 4 & 5 & 5 & 3 & 5 & 4 & 5 & 5 & 59 & 0.19 \\
\hline Hospitality & 3 & 3 & 3 & $\begin{array}{c}3 \\
\text { Total }\end{array}$ & 3 & 3 & 5 & 3 & 3 & 3 & 3 & 4 & 4 & $\begin{array}{c}43 \\
310\end{array}$ & $\begin{array}{l}0.14 \\
1.00\end{array}$ \\
\hline
\end{tabular}

Keterangan:

A : Dinas Perdagangan, Tenaga Kerja, Koperasi, Usaha Kecil dan Menengah

B : Dinas Pemberdayaan Masyarakat dan Desa

C : Dinas Pariwisata Pemuda Dan Olahraga

D : Pemdes Girilayu

E : Pengrajin Batik Wahyu Asih

F : Pengrajin Batik Ridho Rizki

$G$ : Prajnaparamita

H : Kelompok Batik Wahyu Sari

I : Kelompok Batik Sidomukti

$\mathrm{J}$ : Kelompok Batik Vokasi

$\mathrm{K}$ : Kelompok Batik Mekar Sari

$\mathrm{L}$ : Akademisi Pariwisata

M : Pemuda Desa

Setelah bobot diketahui, kemudian responden diminta untuk mengisi kuisioner penilaian masing-masing potensi dan masalah yang telah penulis kelompokkan. Setelah responden memberikan penilaian, kemudian nilai-nilai tersebut dikompilasi dan dilakukan penghitungan skor dari masing-masing potensi masalah. Penghitungan skor dilakukan dengan cara mengalikan bobot dengan nilai yang telah diberikan oleh responden. Setelah diketahui skornya, kemudian dihitung nilai tertimbang dengan cara mengurangkan skor kekuatan dengan skor kelemahan dan mengurangkan skor peluang dengan skor ancaman sehingga diperoleh hasil perhitungan seperti pada Tabel 5.

Tabel 5. Selisih Nilai Tertimbang

\begin{tabular}{|c|c|c|c|c|c|c|}
\hline \multirow{2}{*}{ Variabel (Komponen Desa Wisata) } & \multicolumn{2}{|c|}{ Faktor dari Dalam } & \multirow{2}{*}{$\begin{array}{c}\text { Selisih } \\
\text { Tertimbang }\end{array}$} & \multicolumn{2}{|c|}{ Faktor dari Luar } & \multirow{2}{*}{$\begin{array}{c}\text { Selisih } \\
\text { Tertimbang }\end{array}$} \\
\hline & $\mathbf{S}$ & W & & 0 & $T$ & \\
\hline Atraksi & 31.29 & 5.12 & 26.17 & 7.67 & 6.49 & 1.18 \\
\hline Fasilitas Penunjang & 31.81 & 27.03 & 4.78 & 12.87 & 9.38 & 3.49 \\
\hline Akomodasi & 9.37 & 6.81 & 2.56 & 0 & 0 & 0 \\
\hline Transportasi dan Aksesibilitas & 12.32 & 3.26 & 9.06 & 14.69 & 0 & 14.69 \\
\hline Kesadaran Masyarakat & 7.04 & 15.04 & -8 & 22.65 & 0 & 22.65 \\
\hline Hospitality & 10.96 & 4.16 & 6.8 & 0 & 0 & 0 \\
\hline Total & 102.79 & 61.42 & 41.37 & 57.88 & 15.87 & 42.01 \\
\hline Sumbu & & & X & & & Y \\
\hline
\end{tabular}


Nilai selisih tertimbang yang telah diperoleh kemudian diaplikasikan ke dalam diagram Kartesius untuk mengetahui kedudukan Desa Wisata Batik Girilayu (lihat Gambar 5).

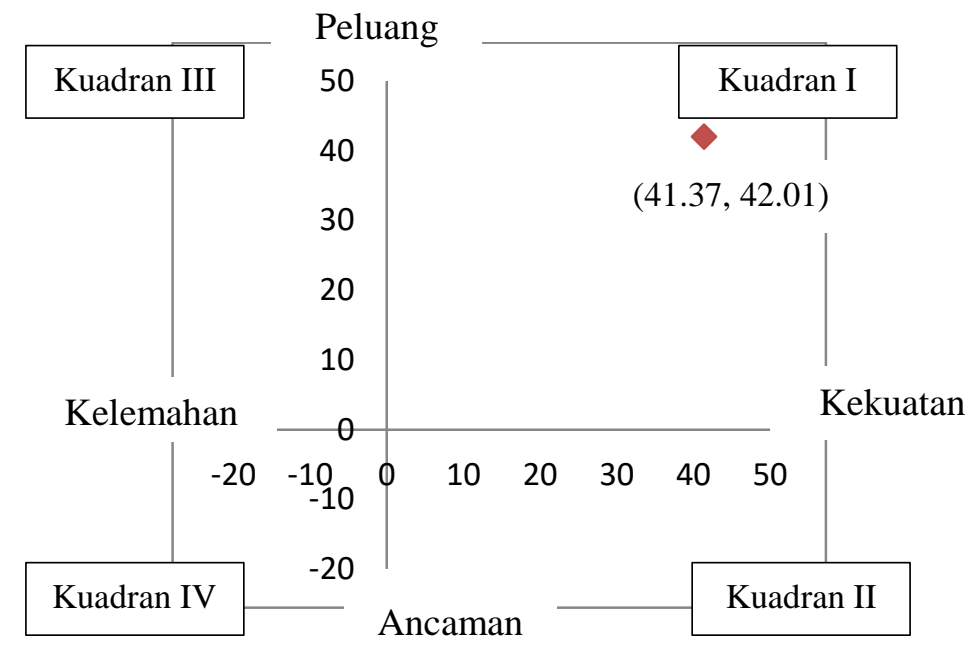

Gambar 5. Diagram Kartesius Kedudukan Desa Wisata Batik Girilayu

Menurut hasil penghitungan nilai setimbang diketahui bahwa kedudukan dari Desa Wisata Batik Girilayu berada pada kuadran I diagram Kartesius, terletak pada koordinat $(41.37,42.01)$ yang dapat diartikan bahwa Desa Wisata Batik Girilayu memilki potensi kekuatan dan memiliki potensi peluang pengembangan. Sehingga untuk pengoptimalan potensi dan peluang yang telah dimiliki maka dapat dilakukan strategi kebijakan pertumbuhan. Apabila nilai selisih tertimbang diterapkan pada diagram Kartesius sesuai dengan komponen wisata, posisi masing-masing komponen wisata pada Desa Wisata Batik Girilayu diperoleh hasil seperti pada Gambar 6.

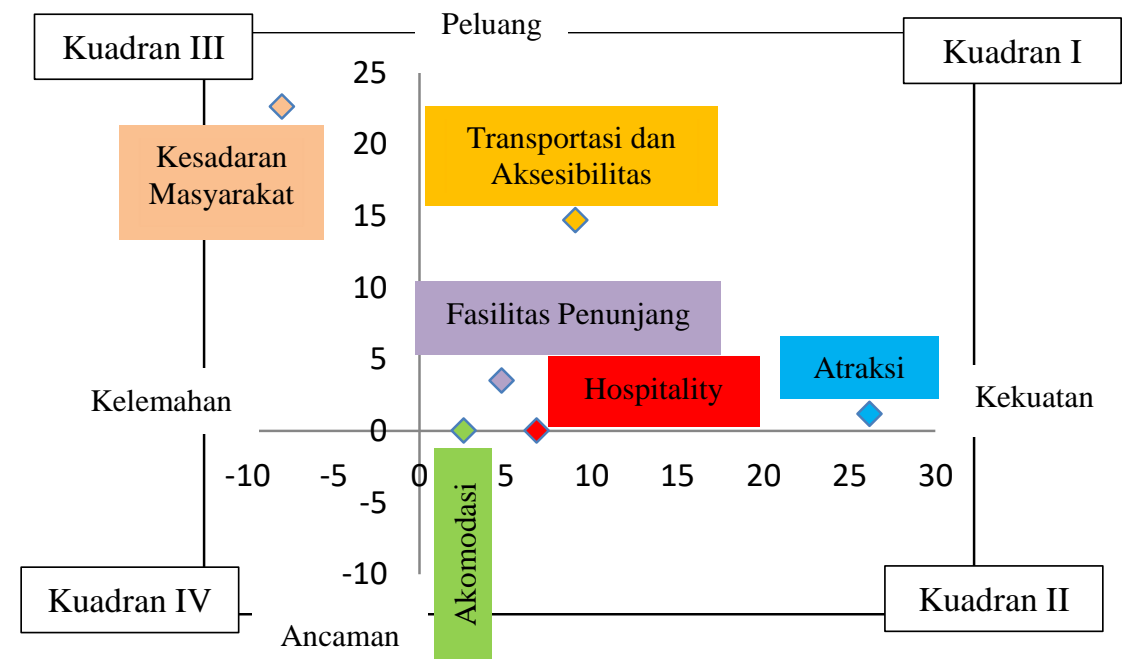

\section{Gambar 6. Diagram Kartesius Penghitungan EFAS-IFAS Komponen Wisata pada Desa Wisata Batik Girilayu}

Dari Gambar 6 dapat diketahui bahwa untuk komponen atraksi, fasilitas penunjang, transportasi dan aksesibilitas berada pada kuadran I diagram Kartesius yang artinya dinilai sudah memiliki potensi kekuatan dari dalam kawasan dan memiliki potensi peluang pengembangan dari luar kawasan. Untuk komponen akomodasi dan hospitality juga berada pada kuadran I diagram Kartesius yang berarti dinilai sudah memiliki potensi dari dalam kawasan, akan tetapi belum memiliki peluang pengembangan dari luar kawasan. Sedangkan untuk komponen kesadaran masyarakat berada pada kuadran III yang berarti 
komponen tersebut dinilai sudah memilki potensi kekuatan dari dalam kawasan akan tetapi potensi ini belum dapat dimanfaatkan sehingga belum mampu mengatasi kelemahan dari desa wisata itu sendiri. Tetapi untuk komponen kesadaran masyarakat dinilai sudah memilki potensi peluang pengembangan dari luar kawasan.

\section{KESIMPULAN}

Berdasarkan hasil penelitian, secara keseluruhan Desa Wisata Batik Girilayu sudah memiliki potensi pada komponen atraksi, fasilitas penunjang, transportasi dan aksesibilitas, akomodasi serta hospitality. Akan tetapi, untuk kesadaran masyarakat dinilai masih kurang karena masyarakat belum mampu memanfaatkan potensi kekuatan dan peluang yang sudah ada pada Desa Wisata Batik Girilayu. Hal ini dapat dilihat pada belum terbentuknya pengelola desa wisata sehingga program yang sudah direncanakan untuk pengembangan desa wisata belum terlaksana dan belum jelas arahnya. Untuk pengembangan Desa Wisata Batik Girilayu kedepan dapat dilakukan pembentukkan pengelola Desa Wisata Batik Girilayu sehingga program desa wisata yang sudah direncanakan dapat direalisasikan. Kemudian dapat pula dibentuk Kelompok Sadar Wisata (Pokdarwis) sebagai wadah masyarakat yang memiliki kesadaran akan potensi wisata yang sudah ada pada Desa Wisata Batik Girilayu sehingga Pokdarwis dapat membantu dalam pengembangan desa wisata. Selain itu, dapat pula menjalin kerjasama dengan objek wisata lain di Kabupaten Karanganyar agar dapat membantu dalam bidang promosi Desa Wisata Batik Girilayu.

\section{DAFTAR PUSTAKA}

Arikunto, S. (2002). Metodologi Penelitian. Jakarta: PT. Rineka Cipta.

Badan Pusat Statistik Kabupaten Karanganyar. (2018, September 26). Kecamatan Matesih Dalam Angka Tahun 2018. Diakses dari https://karanganyarkab.bps.go.id/publication/2018/09/26/c258059a379f573c856b8565/kecamatan-matesih-dalam-angka2018.html

Fandeli, C. (2002). Perencanaan Kepariwisataan Alam. Yogyakarta: Universitas Gadjah Mada.

Inskeep, E. (1991). Tourism Planning: An Integrated and Suistainable Approach. New York: Van Nostrand Reindhold.

Nasution. (2003). Metode Research (Penelitian Alamiah). Jakarta: Bumi Aksara.

Nuryanti, W. (1993). Concept, Perspective and Challenges. Laporan Konferensi Internasional mengenai Pariwisata Budaya (pp. 2-3). Yogyakarta: Gadjah Mada University.

Pendit, N. (1994). IImu Pariwisata Sebagai Pengantar Perdana. Jakarta: Perdana.

Peraturan Daerah Kabupaten Karanganyar Nomor 6 Tahun 2016 tentang Rencana Induk Pembangunan Kepariwisataan Kabupaten Karanganyar tahun 2016-2026. Diakses dari https://jdih.jatengprov.go.id/mobile/produk-hukum-kab-kota/view/?link=rencanainduk-pembangunan-kepariwisataan-kabupaten-karanganyar-tahun-2016-2026-0\&daerah=313

Peraturan Daerah Kabupaten Karanganyar Nomor 1 Tahun 2013 tentang Rencana Tata Ruang Wilayah Kabupaten Karanganyar tahun 2013-2032. Diakses dari https://www.karanganyarkab.go.id/wp-content/uploads/2013/07/PERDA-NO-1-TH-2013.pdf

Priasukmana, S, \& Mulyadin, R. M. (2001). Pembangunan Desa Wiasata: Pelaksanaan Undang-Undang Otonomi Daerah. Info Sosial Ekonomi, 2(1), 34-37. Diakses dari https://biizaa.com/wp-content/uploads/2019/08/6-Panduan-Desa-Wisata.pdf

Rangkuti, F. (2013). Analisis SWOT: Teknik Membedah Kasus Bisnis. Jakarta: PT. Gramedia Pustaka Utama.

Soekadijo, R. G. (2000). Anatomi Pariwisata: Memahami Pariwisata sebagai "Systemic Linkage". Jakarta: PT. Gramedia Pustaka Utama.

Spillane, J. J. (1994). Pariwisata Indonesia, Siasat Ekonomi dan Rekayasa. Yogyakarta: Kanisius.

Suwantoro, G. (2004). Dasar-Dasar Pariwisata. Yogyakarta: Andi.

Undang-Undang Nomor 10 Tahun 2019 tentang Kepariwisataan. Diakses dari https://jdih.kemenkeu.go.id/fullText/2009/10TAHUN2009UU.HTM.

Wahab, S. (1975). Tourism Management. London: Tourism International Press.

Yoeti, O. A. (2002). Perencanaan Strategis Pemasaran Daerah Tujuan Wisata. Jakarta: Pradnya Paramita. 